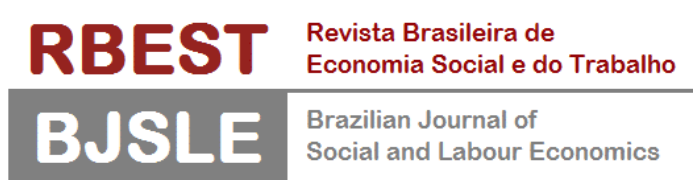

doi: 10.20396/rbest.v1i0.12321

\title{
ARTICLE
}

\section{Uneven and combined globalization}

\author{
Luiz Gonzaga de Mello Belluzzo*
}

\begin{abstract}
The restructuring of capitalism involved profound changes in the way companies operate, in the integration of markets and in the sphere of state sovereignty. Economic globalization has intensified competition between companies, workers and nations. The hierarchical, dollar-led international monetary order has boosted uneven and combined development. The aim of this paper is to stimulate reflection on contemporary capitalism from the perspective of political economy. The dynamics of financial flows and the increase in wealth stocks have had impacts on macroeconomic management, job creation and income distribution in developed countries. The early deindustrialization of Latin American economies and the consistent industrialization of Asian economies altered the international division of labor and differentiated the capitalist periphery. The financialization of wealth and the empowerment of rentierism have constrained most governments to work towards full employment and social protection. The widespread global value chains and the redefining of the pattern of competition by large corporations have negatively affected unions and the labor market, increasing unemployment (even if in disguise) and precarious labor relations.
\end{abstract}

Keywords: Globalization; Financialization; Macroeconomic policy.

JEL: D3, E2, G1, G3, F4, F6, J2.

* Instituto de Economia, Universidade Estadual de Campinas (Unicamp); Faculdades de Campinas (Facamp), Brasil.

Orcid: https://orcid.org/0000-0002-8000-6538

E-mail: belluzzop@terra.com.br

\section{$($ (c) $)$ BY-NC-SA}

Editor's note: An earlier version of this text (written in Portuguese) was published in the book $A$ escassez na abundância capitalista (Belluzzo \& Galípolo, 2019). Translated by Lício da Costa Raimundo. 


\section{Resumo}

\section{Globalização desigual e combinada}

A reestruturação do capitalismo envolveu mudanças profundas no modo de operação das empresas, na integração dos mercados e na esfera de soberania do Estado. A globalização econômica acirrou a competição entre empresas, trabalhadores e nações. A ordem monetária internacional hierarquizada, comandada pelo dólar, potencializou um desenvolvimento desigual e combinado. O objetivo do artigo é estimular a reflexão sobre o capitalismo contemporâneo pela ótica da Economia Política. A dinâmica dos fluxos financeiros e o aumento dos estoques de riqueza produziram impactos na gestão macroeconômica, geração de empregos e distribuição de renda nos países desenvolvidos. A desindustrialização precoce de economias latino-americanas e a industrialização consistente de economias asiáticas alteraram a divisão internacional do trabalho e diferenciaram a periferia capitalista. A financeirização da riqueza e o empoderamento do rentismo restringiram a atuação da maioria dos governos em prol do pleno emprego e da proteção social. A difusão das cadeias globais de valor e a redefinição do padrão de concorrência de grandes corporações afetaram negativamente os sindicatos e o mercado de trabalho, aumentando o desemprego (mesmo que disfarçado) e a precariedade das relações de trabalho.

Palavras-chave: Globalização; Financeirização; Política macroeconômica.

\section{Resumen}

\section{La globalización desigual y combinada}

La reestructuración del capitalismo significó cambios profundos en el modo de operación de las empresas, en la integración de los mercados y en la esfera de la soberanía del Estado. La globalización económica ha intensificado la competencia entre empresas, trabajadores y naciones. El orden monetario internacional jerárquico, dirigido por el dólar, potencializó un tipo de desarrollo desigual y combinado. El objetivo de este artículo es estimular la reflexión sobre el capitalismo contemporáneo desde la óptica de la economía política. La dinámica de los flujos financieros y el aumento del stock de riqueza han tenido un impacto en la gestión macroeconómica, la creación de empleo y la distribución del ingreso en los países desarrollados. La desindustrialización temprana de las economías latinoamericanas y la industrialización constante de las economías asiáticas alteraron la división internacional del trabajo y diferenciaron la periferia capitalista. La financiarización de la riqueza y el empoderamiento del rentismo redujeron la participación de la mayoría de los gobiernos en pro del pleno empleo y la protección social. La difusión de las cadenas globales de valor y la redefinición del patrón de competencia por parte de las grandes corporaciones han afectado negativamente a los sindicatos y al mercado laboral, aumentando el desempleo (incluso disfrazado) y la precariedad de las relaciones laborales.

Palabras clave: Globalización; Financiarización; Política macroeconómica.

\section{Résumé}

\section{Mondialisation inégale et combinée}

La reestructuration du capitalisme e entraîné de profonds changements dans le mode de fonctionnement des entreprises, dans l'intégration des marches et dans la sphère de la souveraineté des États. La mondialisation économique a intensifié la concurrence entre les entreprises, les travailleurs et les nations. L'ordre monétaire international hiérarchisé, dominé par le dollar, a favorisé um dévelloppement inégal et combine. Le but de cet article est de stimuler la réflexion sur le capitalisme contemporain du point du vue de l'économie politique. La dynamique des flux financiers et la hausse des stocks de richesse ont a eu une incidence sur la gestion macroéconomique, la création d'emplois et la répartition des revenus dans les pays développés. La désindustrialisation precoce des économies latino-américaines et I'industrialisation cohérente des économies asiatiques ont modifié la division internationale du travail et différencié la périphérie capitaliste. La financiarisation de la richesse et l'autonomisation du rentier ont contraint la plupart des gouvernements à oeuvrer pour le plein emploi et la protection sociale. Les chaînes de valeur mondiales répandues et la redéfinition du modèle de concurrence des grandes entreprises ont eu um impact négatif sur les syndicats et le marché du travail, entraînant chômage (même déguisé) et des relations de travails précaires.

Mots clés: Mondialisation; Financiarisation; Politique macroéconomique. 


\section{Introduction}

History does not repeat itself, but rhyme, Mark Twain would have said. We begin the reflection on globalization in good company. Let us rhyme the vicissitudes of the contemporary social and economic environment with the tribulations of the 1920 s and 1930s. Both that time and the current historical conjuncture reveal an increasingly powerful capitalism in its capacity to create and destroy, to turn competition into a monopoly, to practice protectionism, to destabilize national currencies, to cause unemployment among men, and to stop machinery. They also reveal that societies can react to the blind and disruptive violence of "economic laws" with the weapons of brutality and political voluntarism.

The fascist economic regime was a monstrous movement against the pseudoobjectivity of economic laws and their dire consequences for the living conditions of individuals. The negative experience of the 1920s and 1930s left a lesson: capitalism of big business and financial capital would inexorably push society to the brink of other totalitarian adventures if a public decision-making body were not set up to coordinate and discipline the private mega-power.

In order to avoid a repetition of the disaster, it was necessary, first of all, to constitute an international economic order capable of encouraging the unimpeded development of trade among nations, within monetary rules that would guarantee confidence in the reserve currency, non-deflationary adjustment of the balance of payments and the liquidity supply required by the expanding transactions. It was about building an international economic environment designed to provide a wide range of maneuvers for national development, industrialization and social progress policies.

The institutions and economic policies of the Social State were committed to the maintenance of full employment, with the attenuation, in the name of equality, of the damages caused to the individual by the free operation of the "economic mechanism". The conception of a national development, within the framework of a stable and regulated international order, was not an idiosyncratic fantasy, or "forty years of stupidity", as an unexpressive character of Brazilian economic thought put it.

The "social" and "inter-national" capitalism of the Golden Age (1948-1973) was transfigured into "global", "financialized" and "unequal" capitalism. Economic disarticulation reveals a new phase, marked by disagreements in the relations between the functioning of globalized markets and national legal-political spaces.

In the face of the nervousness of the economic insecurity, political polarization has intensified, fomented by the growth of the mass of those who have had their conditions of 
work and life precarious in the way of the geographical arbitration of wages, taxes, exchange and interest by the globalized finance. The "irrationals" want the jobs back. The scenario recalls the "closure" of economies in the Great Depression years. It is worth revisiting the Tariff Act text of the 1930 Smoot-Hawley Act, which brutally raised tariffs and launched international trade in the deflationary collapse.

Political polarization expresses in a dramatic way the breakdown of the more "balanced" relations between the powers of the "free market" and the protection of the economic and social rights of the disadvantaged citizens.

In the face of the heated contemporary debate, we seek to escape from the vision that seeks to move the controversy towards the assessment of the benefits and losses of globalization. Our purpose is to avoid binary simplifications and to look at the dynamics of capitalist structures after the crisis of social and political arrangement that underpinned the way the central and peripheral economies functioned in the Thirty Glorious Years.

\section{The reconfiguration of the international economic order}

In the 1970s the experience of the "social" and "inter-national" capitalism suffered from the malaise of the first oil shock, stagflation, and peripheral indebtedness fueled by the recycling of petrodollars. Inflation succumbed to Paul Volcker's surge in interest rates in 1979. In addition to launching the country into recession, the Federal Reserve gesture not only flattened double-digit inflation in the United States, but above all reinstated the dollar's sovereignty as currency, extinguishing the threat of fractionation of the international monetary system. Volcker's stab dismantled the pretensions of the Europeans to direct the substitution of the dollar for a reserve asset managed by the IMF and backed by a basket of currencies.

The 1970s is also the time of China-US rapprochement, promoted by Nixon and Kissinger. From a geopolitical and geoeconomic perspective, the inclusion of China in the context of American interests is the starting point for the expansion of the borders of capitalism, a movement that would culminate in the collapse of the Soviet Union and the strengthening of the values and proposals of the neoliberal ideology.

The awakening of the second globalization was marked in the early 1980s. Below, we list the main factors that drove the expansion and transformation of the new globalized economy (Belluzzo \& Galípolo, 2017):

1) financial deregulation and the opening of capital accounts led to the continued growth of gross capital flows between national economies, especially for the American market; 
2) the appreciation of the dollar intensified the migration of manufacturing to low-cost countries;

3) the intensified competition between large companies has boosted the new spatial distribution of globalized production;

4) the spatial redistribution of the manufacturing industry was accompanied by hyperindustrialization, that is, the rapid introduction of hand-saving methods and technologies;

5 ) the formation of successive bubbles of appreciation of real and financial assets supported by financial "leverage";

6) the insignificant growth in workers' incomes (many of which became "precarious") in the central countries accompanied the reduction of poverty in the industrializing periphery;

7) the consequent widening of inequalities in the distribution of income and wealth;

8 ) the excessive indebtedness of families in the United States and in the European "periphery";

9) the degradation of progressive taxation systems and the shrinking of social protection;

10) the persistence of encouraged fiscal deficits and the expansion of government debt;

11 ) the metamorphoses of wealth imposed the predominance of rentier rationality.

The most important dimension of the so-called "financial deregulation" is the progressive opening of the capital accounts that followed the reaffirmation of the dollar as reserve currency in 1979. Thus, at the top of the hierarchy of factors that brought about the dynamics of financial internationalization, between central economies, particularly between Wall Street and City of London. The consequences of financial deregulation and the opening of capital accounts go far beyond what can be observed in the balance of payments records. The most important effects of the mobility and globalization of financial capital are: i) the generalization of debt and credit relations in foreign currency; ii) the exceptional growth of the organized and over-the-counter markets for the trading of derivatives for protection against interest and exchange rate fluctuations; and iii) transfers of assets between residents and non-residents mediated by funds managed by large financial institutions.

The "mismatching of currencies" in the balance sheets of the relevant agents is not visible in the net results revealed by the observation of current account deficits or surpluses between countries. Thus, according to Claudio Borio (2013), economist at Bank for International Settlements (BIS), even if the United States did not show external deficits throughout the 1990s (and the first decade of the 21st century), capital inflows would have been robust.

In concomitance with the rapid growth of capital flows, there has been a gradual relaxation of what has been called "financial repression". In the United States, in 1999, the Gramm-Leach-Bliley Act defeated the 1930s legislation (the Glass-Steagal Act, which 
separated deposit banks, investment banks, insurance companies and institutions for real estate financing and savings). Portfolio investment inflows into the net and deep US market were accompanied by the advancement of "securitization", with increasing participation of households and surplus companies as fund providers and role holders through institutional investors (pension funds, mutual funds and insurers).

Diagram 1

Capital flows between Europe and the United States

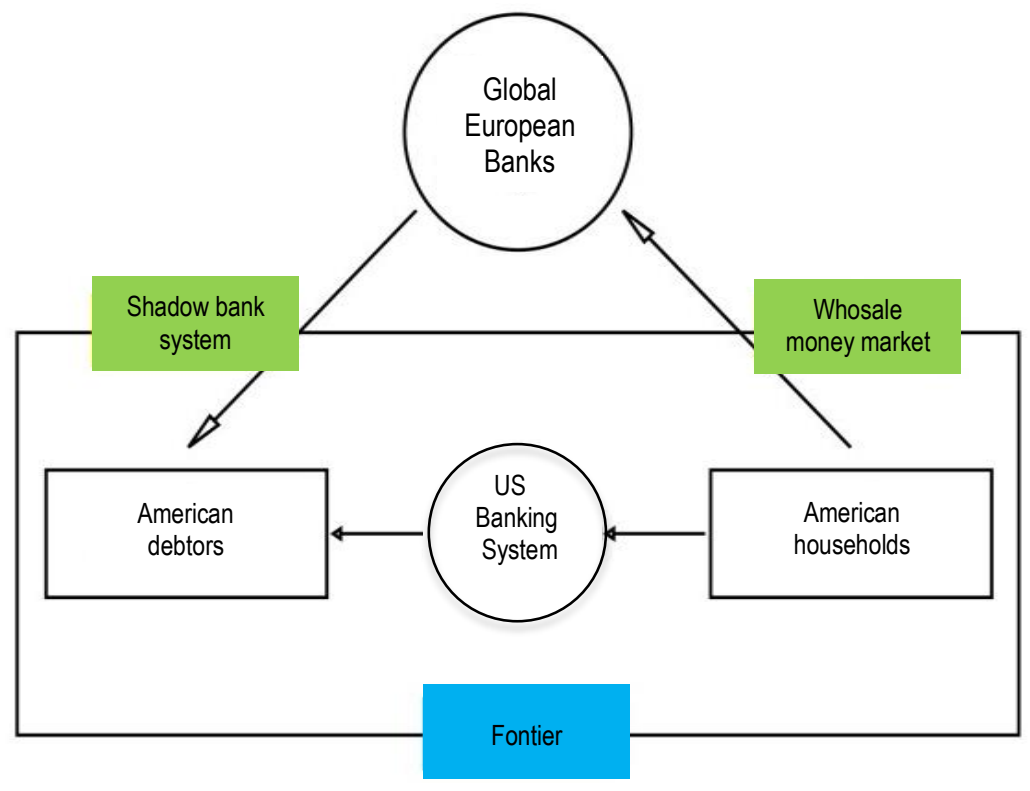

At the other end, debt issuers are primarily National Treasuries (with prominence in the United States), large corporations, banks, and middle-income and low-income families. Unlike the postwar period up to the early 1980s, the transformation of assets into bank loans gave way to direct finance, mobilized through the markets of assets.

Securitization and leverage have built a web of debt and credit relationships among the major institutions around the world. Investment banks and other shadow banks have moved closer to the monetary functions of commercial banks, fueling their liabilities in the "wholesale money markets", supported by the short-term applications of companies and households. Not coincidentally, intra-financial debt as a proportion of US GDP grew faster than household and corporate indebtedness. This phenomenon corresponds to the control of social wealth by private institutions, which makes it impossible for central banks to fail when a chain link is broken. 
The liquidity and depth of the American financial markets financed and guaranteed the exit of productive capital and the consequent American deindustrialization. Since the mid1980 s and more intensively over the next two decades, manufacturing investment by internationalized firms has been concentrated in China and emerging Asia.

\section{Graphic 1. Capital account as a percentage of GDP (\%)}

USA: $1960-2008$

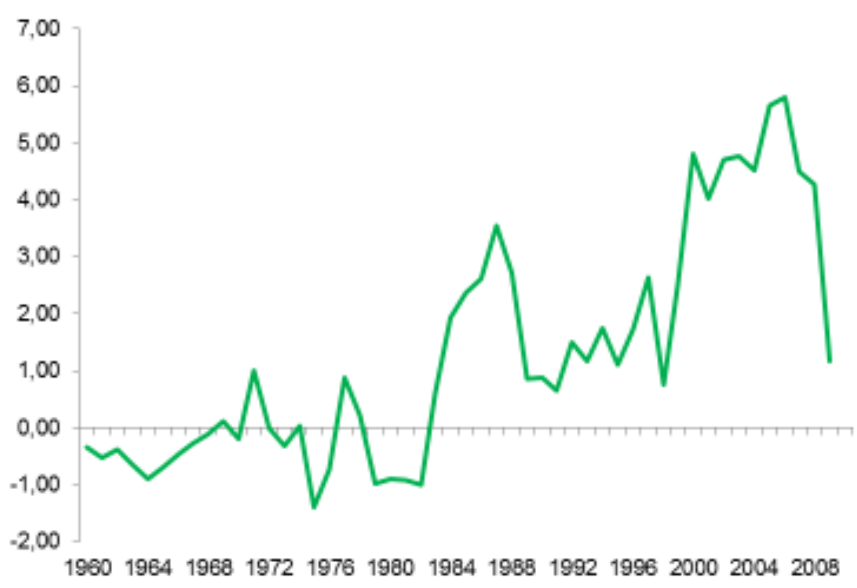

\section{Graphic 2. Foreign Direct Investment as a percentage of GDP (\%)}

USA: $1960-2008$

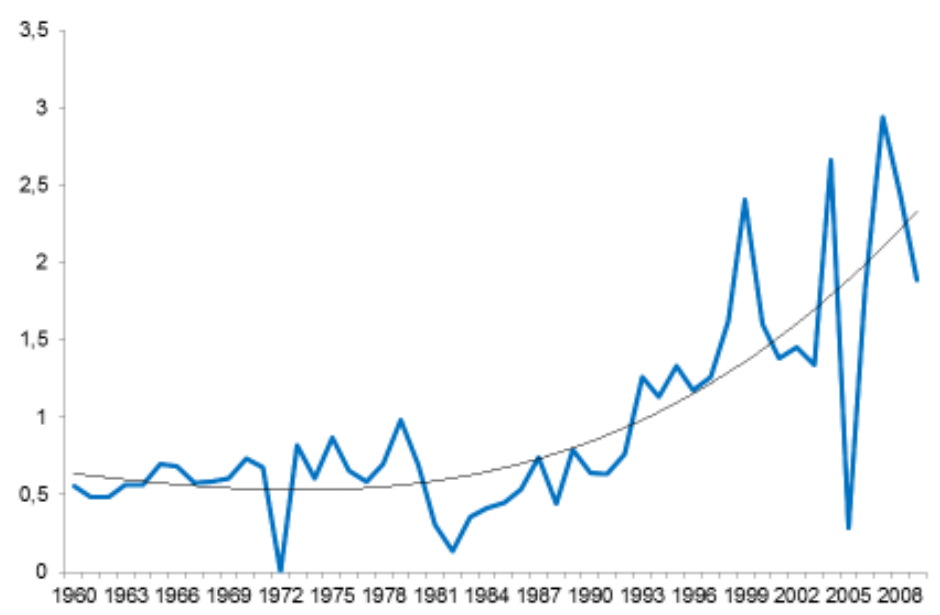

During this period, China's "competitiveness" has skyrocketed, both in the less technologically skilled and in the more sophisticated technology areas. The acceleration of the investment rate in the Asian emerging countries has led to the rapid accumulation of productive capacity in almost all sectors related to foreign trade. 
The connections between investment in China's manufacturing industry and the rate of growth of exports are obvious. The good performance of exports and the public investment in infrastructure promoted the growth of employment, the income of Chinese families and the maintenance of a high level of occupation of productive capacity.

Chinese leaders have used the "openness" of the economy to foreign investment eager to seize the abundant supply of labor. China opted for the favorable combination of real competitive exchange, dominance of state banks in the supply of credit, low interest rates to undertake national investment strategies in infrastructure, absorption of technology with exceptional gains in scale and scope, industrial chain exports.

\section{Graphic 3. Foreign direct investment according to region of origin (US\$ billions)} China: $1965-2005$

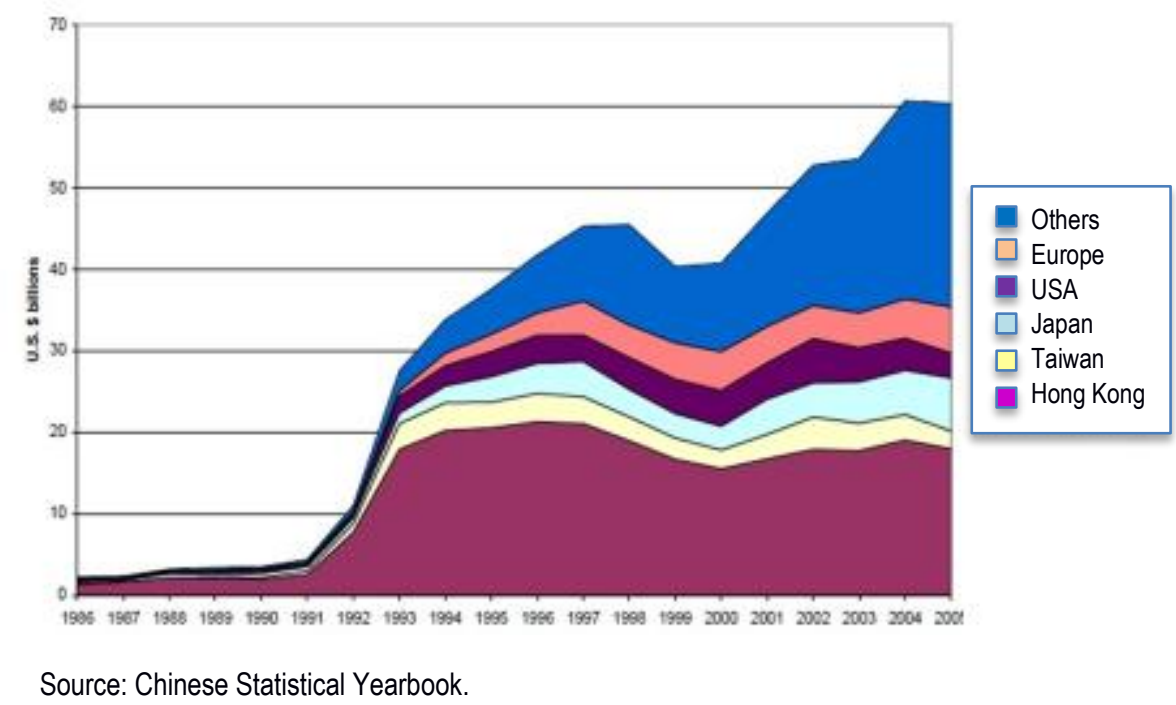

Professors Chandrasekhar and Jayati Ghosh (2018), supported by IMF data on the world economy, report the decline in the share of advanced economies from 83 percent to 60 percent over the past three decades. The bulk of this change occurred between 2002 and 2013 , when participation declined from $80 \%$ to $62 \%$, due to the increase in China's share of $3 \%$ to $15 \%$, which accounts for $87 \%$ of the decline in the share of advanced economies in the period between 1980 to 2015.

The book China versus West by Ivan Tselichtchev (2012) gives the dimension of the transformation occurred. In the 1980s the Chinese economy held the same $1 \%$ of Brazil's share of world trade, in 2010 its share jumped to $10.4 \%$, against $8.4 \%$ of the US, $8.3 \%$ of Germany. During the first decade of the new millennium the average annual growth rate of 
the Chinese economy was $10.5 \%$, against $1.7 \%$ in the US and $0.9 \%$ in Germany. By the end of the decade, China accounted for $42 \%$ of the world's production of color TVs, $67 \%$ of video products, $53 \%$ of mobile phones, $97 \%$ of PCs, and $62 \%$ of digital cameras.

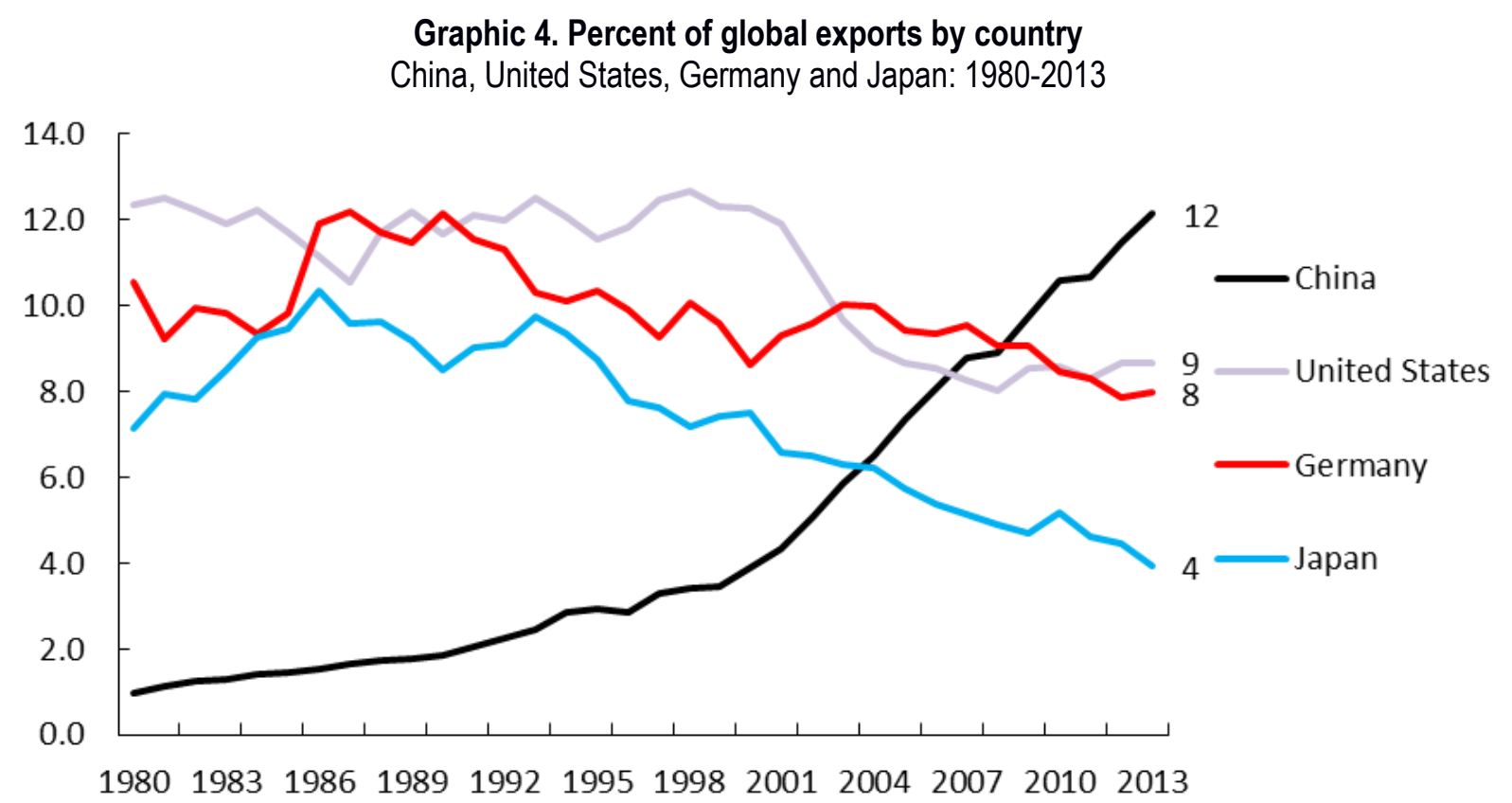

Source: IMF Direction of Trade Database; World Trade Organization. Extracted from Rutkowski (2014, May 1).

The Unctad Trade and Development Report 2003 brings the subtitle Capital accumulation, growth and structural change. A thorough and accurate evaluation of the results of development policies in Asia and Latin America over the last two decades. This is a historical-comparative study of the performance of developing countries in the course of the transformation of the global economy in the 1980s and 1990s:

1) those of mature industrialization such as Korea and Taiwan that have already reached a high degree of industrialization, productivity and income per capita, but show a declining rate of industrial growth;

2) those of rapid industrialization, such as China and perhaps India which - through policies favoring high rates of domestic investment and technological graduation - show a growing share of manufactures in output, employment, and exports;

3) those of enclave industrialization, such as Mexico, which, despite increasing their share of manufactured exports, perform poorly in terms of total investment, manufacturing value and productivity; and 
4) finally, the countries in process of de-industrialization, which includes most Latin American countries.

The typology drawn by Unctad (2003) is the point of arrival of the complex game. In all stages of the expansion of capitalism this game involves the financial, technological, patrimonial and spatial transformations that result from the interaction of two movements:

a) The competition process moved by the large company, under the tutelage of the nuclear institutions of "governance" of the system: finance and the hegemonic state;

b) The national "insertion" strategies of peripheral regions. The transformations that we see today are driven by the strategic game between the "dominant pole" - in the case of the American economy, its technological capacity, the liquidity and depth of its financial market, the power of seignorage of its currency - and the ability to "answer" of developing countries to changes in the international environment.

Needless to say, peripheral economies have very dissimilar social, economic, and political structures and trajectories, making it difficult for some and facilitating for others the so-called "competitive integration" in the various stages of capitalism's evolution. Thus, for example, the success of Brazil until the early 1980s triggered the crisis that would provoke its repeated "failure" in trying to adjust to the new international conditions. On the other hand, Chinese failure until the 1980s provided more favorable initial conditions for the success of the reforms undertaken thereafter.

\subsection{Financialization, debt, and consumption}

The "American globalization", operating in the financial, patrimonial and productive orbits, generated two types of regions: those whose international insertion is made by attracting direct investment destined to productive sectors affected by international trade; and those, such as Brazil and Argentina, who sought their integration through passive trade liberalization and the flexibilization of the capital account.

The opening of the capital account promoted the "financialization" of the exchange rate. Subject to the short-term expectations of financial markets, exchange rates showed a strong tendency towards appreciation and, worse, volatility, subordinating domestic monetary policies to the empire of the interest differential between convertible currencies and nonconvertible peripherals currencies.

The spatial redistribution of the manufacturing industry has widened imbalances in the balance of payments between the US, Asia and Europe, as well as reinforced the so-called financial globalization (Belluzzo, 2016). As has been said, the US was able to attract capital 
to finance current account deficits with leftovers and thus maintained low interest rates, valued dollar, cheap imports and inflationary lull. The widening US current account deficit was offset by rapid accumulation of reserves in emerging countries - in manufactures and commodity exporters, including oil tankers. Used in the purchase of American assets, the "savers" reserves helped to sustain low interest rates, the astounding expansion of credit, which encouraged asset inflation and stimulated household consumption.

Graphic 5. Current account as a percentage of GDP (\%)

USA: $1960-2008$

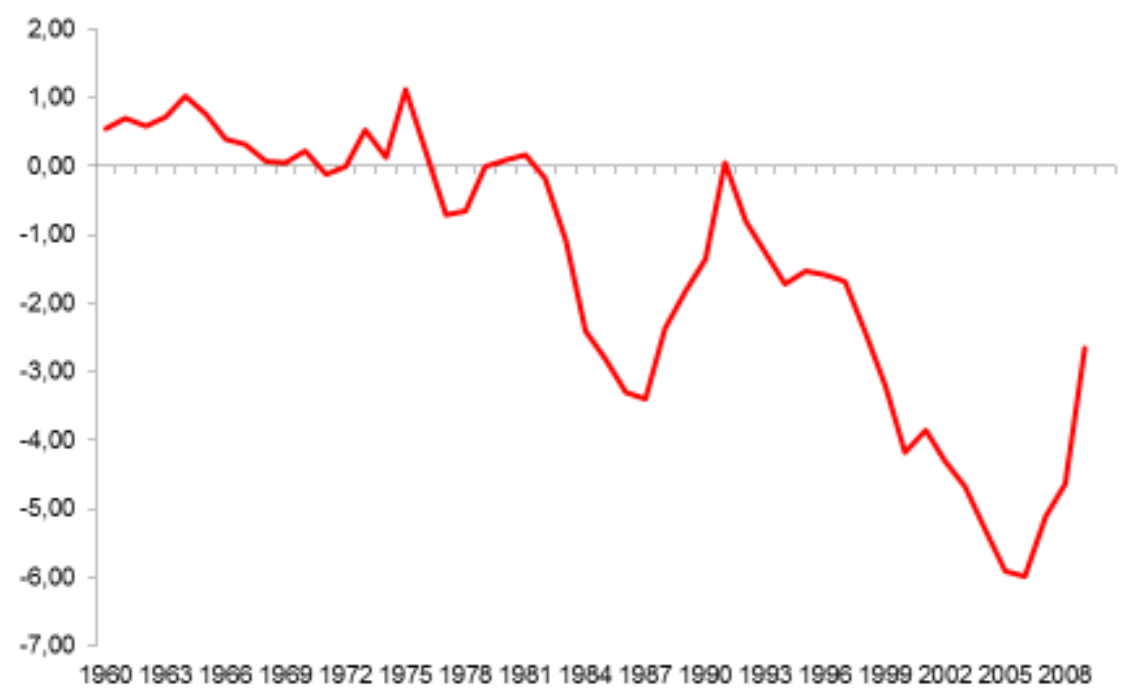

Household consumption expenditures increased their share of aggregate expenditure and became the most important component of the growth rate of more developed economies, especially in the United States, England and European peripherals. On the other hand, consumption ceased to have the relatively stable behavior predicted by the Keynesian consumption function and started to present a typical instability of investment decisions.

It is not just that a fraction of consumption ceases to be proportional to current income, a phenomenon that is established by the generalization of consumer credit. It means that it significantly increases the possibility of "leverage" by consumers. This leverage is the result of the perception of families and their financiers regarding the accelerated valuation of the financial and real estate assets that accumulate in their portfolios. The wealth-effect, it is said, is not realized through the sale of the assets, with the conversion of the monetary result into consumption, but through the expansion of the demand for credit by the "enriched" consumers. 
Graphic 6. Household debt relative to disposable income (DI) and GDP (\%) USA: $1980-2011$

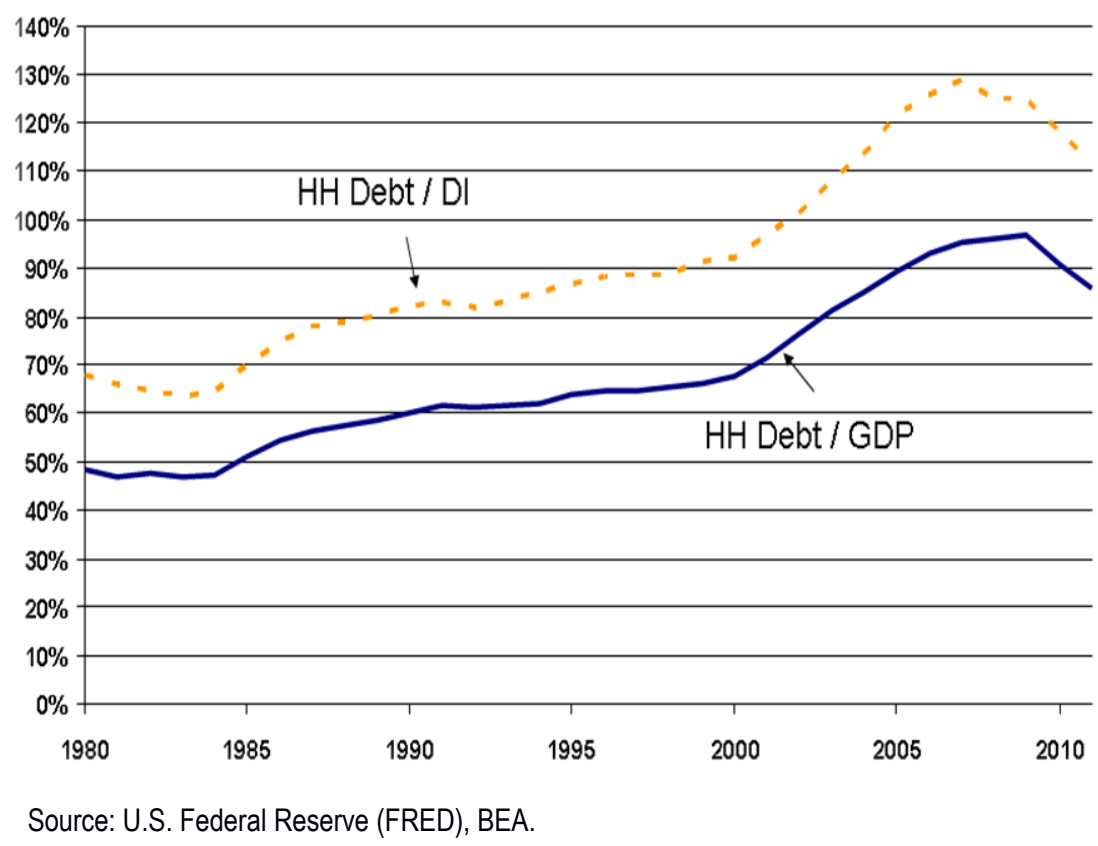

Confident in an upward trend of appreciation of their wealth, consumers tend to raise the propensity to consume over current income, supported by increased indebtedness. The prospect of accelerated enrichment begins to command consumption spending decisions: the level of indebtedness is no longer calculated on current income but rather on the expectation of growth of the prices of the assets that make up the family portfolio. Thus, it is possible to observe increases in the current debt/income ratio, although the relation between debt and the stock of wealth can remain stable or even decline.

The so-called "financialization" involves the capture of expressive groups of the population by the wealth effect and engenders a cycle of valuation of assets with force to excite the demand far beyond the normal expectations of the entrepreneurs who produce consumer goods and capital goods. The Sino-American arrangement that has commanded the global growth show in recent years has driven the effects of the excitement of Uncle Sam's consumerism to balance-of-payments deficits and shifted corporate investment decisions to rapidly emerging industrial, with little pressure on prices. Claudio Borio and Piti Disyatat (2011) countered orthodoxy's arguments about the effectiveness of inflation targets. They argue that global factors have become more important than domestic factors, and refers to the important changes that affected, before the financial crisis, the conditions of supply and 
demand in the globalized economy. The price increases caused by the excitement of demand are limited to services and other goods not involved in foreign trade.

The productive investment decisions in the new areas, in turn, suffered a triple influence of the inflation of assets: 1 ) the overheating of the consumption, excited the expectation of profits of the industry, with the known effects on the demand of commodities; 2 ) the increase in the value of shareholders' equity - through an increase in the market value of the company - and the consequent increase in the capacity of corporate indebtedness (thus, although companies were involved in an investment effort and in the merger/acquisition process, the debt/equity ratio remained stable, or even declined); 3) the consequent reduction of capital costs to the company better evaluated by the rating agencies lowered the perception of risk to lenders and to borrowers.

The recent economic cycle has "internationalized" the information that promotes investment promotion. The indices that measure the confidence of American and European consumers have risen persistently, due to the reduction of the unemployment rate and the continued appreciation of residential assets. Emerging people have witnessed the "Kaleckian" phenomenon of reinforcing the virtuous circle: increasing investment produces an increase in profits. In the United States and China, the increase in profits led to a higher appreciation of the shareholders' equity of the companies, which was reflected in a further appreciation of the shares. The credit system, with high levels of liquidity, adjusts to elastically meet the demand for new loans.

As in the every expansionary cycle, the demand price of real assets and financial assets tends to grow together. In the recent cycle, driven by asset inflation, asset market price growth was much faster than the flow of income. One of the hallmarks of stock market capitalization and the explosion of real estate assets was the dramatic rise in price/earnings and price/rent ratios.

Predictably, an abrupt collapse of "wealth" prices would inevitably lead to the economy on the verge of depression, due to the cumulative and self-reinforcing character imposed by asset deflation. Faced with the leverage that sustained their "enrichment", families and businesses were "surprised" by a strong growth of their debts. The degree of indebtedness increased both in relation to current income and in relation to the respective assets. In the case of non-financial corporations, the perception that the debt/equity ratio grows unintentionally, with deterioration of the rating, has made it more difficult to borrow new loans. This deterioration of the market value of the companies and their indebtedness situation then caused, at that moment, further devaluations of their actions. In the absence of more incisive intervention by governments, the world economy would plunge into depression. 


\section{Metamorphoses of capitalist wealth and the advancement of rentier}

The financial crisis triggered in 2008 can not be attributed to an incident of mismanagement of relevant market players - large financial institutions and internationalized corporations. Mainstream economists use the concepts of market failures determined by information asymmetry, moral hazard, etc. to explain the crisis. As the Italian economist Giancarlo Bertocco (2017) points out, the crisis is born of the endogenous transformations promoted by the capitalist dynamics that led to the exasperation of financial, productive imbalances and the distribution of income and wealth among countries, companies and families. It is not an accident caused by asymmetric information or the formation of "reckless" speculative positions. Nevertheless, the development of the inherent tendencies to the process of accumulation of abstract wealth.

The book of Thomas Piketty, Capital in the Twenty-First Century, will be taken as a reference to analyze the metamorphoses of wealth and its distributive effects. Piketty is well-known the paths of relations between wealth and income from the predominance of land wealth - whose decline was imposed by the forces of mercantilist policies of incentive to manufacture - to the contemporary arrangements dominated by financial patrimonialism and the concentration of capital in the large oligopolies that dominate all sectors of industry and services in the global arena. The transformations in the financial system unleashed free and brutal competition in the capitalism of big business and big financial institutions.

Here we will deal with the changes that occurred between the 1970 s and the financial crisis in 2008. In his pilgrimage, Piketty (2014) presents a concept of capital that apparently disregards Marx's theoretical formulations of capitalist relations of production and their connections with the nature of the productive forces suited to the development of this system of production.

However, by aggregating the various modalities of assets and discussing changes in their composition, Piketty reconstitutes Marx's trajectory in Capital: he reaffirms the "nature" of the capital regime as a historical modality whose purpose is the accumulation of monetary, abstract wealth; thus opening space for the understanding of the dominance of capital at interest and of fictitious capital as forms of wealth and enrichment derived from the ownership of capital and not from the innovative and faustic activity of the capitalist entrepreneur. The necessary interdependence of capitalist wealth in its more "advanced" modalities confirms the investigations of Marx, Schumpeter, Keynes, and Minsky on the laws of motion governing the relationship between wealth, income, and value creation. 
In capitalism charged with all its determinations, aggregate wealth is the set of reproductive assets, property rights over these assets and their income (capital stocks), and debt securities generated over several cycles of value creation. Financial assets - bonds and debt securities - are valued daily in specialized markets.

In Book III of Capital, Marx establishes the connection between the expansion of credit and the valuation of financial assets. He explains that by developing available capitalmoney, the mass of profitable values, state bonds and shares is also developped. However, at the same time it increases the demand for available money, since those who speculate on securities play a fundamental role in the money market. If all purchases and sales of these securities were nothing more than the expression of the real investments of capital, it would be correct to say that they do not influence the demand for loan capital (Marx, 1894/1984).

In 1931, one year after the publication of Treatise on Money, Keynes clarifies his point of view on the integration of money and credit into asset ownership decisions. He argues as follows:

There is a multitude of real assets in the world, which constitute our wealth of capital: constructions, inventories of goods, goods in process of production and transportation, and so on. The nominal owners of these assets, however, have often borrowed money to get hold of them. On the other hand, true wealth holders hold rights not over real assets but over money. A considerable part of this funding comes through the banking system that interposes its broad guarantee among depositors, who lend money, and borrowers who seek these funds to finance the purchase of real assets. The interposition of this monetary veil between the real asset and the possessor of wealth is the hallmark of the modern world. (Keynes, 1973, p. 151).

\subsection{Flows (income) and stocks (wealth)}

The national income is the flow created by the expenditure of investment and consumption, the value itself in movement. The contrast and symbiosis between these forms of value outside the production process: the quest for competitiveness and market control relies on gains in labor productivity by introducing new generations of fixed capital, raw materials, parts and components into detriment of the number of workers (living labor), while at the same time it depends on the latter for the production and realization of value.

Economists Wynne Godley and Marc Lavoie (2007) start from Keynesian macroeconomics to build a dynamic model in which "cash flows" promote composition changes 
in wealth stocks. Assets of someone are liabilities of others, that is, debts of someone are rights of others. Preferred shares are rights that prioritize the company's income and the common shares confer the right to seek control of the property. Families acquire over time spot-deposits, government bonds, stocks and bonds issued by banks or directly on capital markets by corporations. They are an inescapable way to accumulate wealth in a monetary economy. Companies issue shares and are indebted to banks and other financial intermediaries to raise funds necessary to finance their activities - those needs that exceed retained earnings. Governments finance spending by issuing government bonds in close cooperation with central banks that regulate money market liquidity conditions through the daily repurchase of eligible government and private sector bonds.

Commercial banks and other financial intermediaries operate in the space created by the central banks' guaranteeing operations and regulate the supply of credit to the nonfinancial corporate sector, supported by the "creation" of liabilities, demand deposits and, in the alternative, the debt to the public. Non-bank financial institutions leverage asset positions in liabilities in wholesale money markets.

The interrelationship between the balance sheets - assets and liabilities - of the relevant agents, banks, companies, families, government and external sector, places financial institutions at the top of the decision-making processes of expenditure, income formation and management of asset stocks generated. Banks and other financial institutions exert the prerogative to leverage loans to generate deposits, create currency, and accommodate reconfigurations of property rights (stocks and bonds) that are born and transformed into the process of accumulation of value and wealth. Simplified, the movement will create liquidity by granting new credit to finance investment and consumption expenditures - for income generation, with the consequent accumulation of assets and liabilities in the agents' balance sheets. Godley and Lavoie (2007, p. 17), in analyzing the flow of funds and changes in the composition of stocks between the beginning and the end of each period, introduce historical time in capitalist dynamics:

We start each period with a configuration of inventories that changes due to the new flows generated over the period. The system does not generate equilibrium tendencies, nor the imbalance, but a sequence of transformations in the balance sheets of banks, companies, governments, families and the external sector.

The sequential analysis of the dynamics between flows and stocks makes it possible to clarify the processes of "imbalance" in the relations between wealth and income and reveals that the concentration of wealth in the hands of rentier owners increases the "marginal 
propensity to save" for each level of income, depresses private spending, as well as deepens inequality in the distribution of income.

As a general rule, the distribution of wealth is much more concentrated than the distribution of income. Thus, the greater propensity to spare of those in the upper tiers of income distribution contributes to depressing the propensity to spend of the private sector.

The frugality of the rich expands the role of inheritance in the reproduction and accumulation of wealth, which belies the meritocratic and "competitive" character of the enrichment claimed by the liberals. By deploying wealth in the ways in which it has been transmuted over the course of three centuries of history, Piketty (2014) makes reappear in the proscenium of economic life the "natural" tendency of capitalism to the pre-eminence of capital-property and the valuation of existing assets over the adventures of productive investment. He argues that when the entrepreneur inevitably tends to become a rentier, dominant over those who have only their own labor, capital reproduces more rapidly than increased production, and the past devours the future.

In the article "Capital is back", Thomas Piketty and Gabriel Zucman (2014) reveal the evolution of the relationship between wealth and income since the eighteenth century. Analyzing the world's eight largest developed economies, the share of aggregate wealth rises from approximately $200-300 \%$ in 1970 to $400-600 \%$ today.

The curve that expresses the evolution of this relation presents the " $U$ " format, with a sharp fall in the share of aggregate wealth over income in the period comprising the two great world wars and the Great Depression. The trend has been reversed more sharply since the 1970s. According to the authors:

The world wars and anti-capital policies destroyed a large fraction of the world's capital stock and reduced the market value of private wealth, which is unlikely to occur again in the era of deregulated markets. On the other hand, if there is a reduction in income growth in the decades ahead, then wealth-income relation can become high around the world. (Piketty \& Zucman, 2014, p. 1260).

In this paragraph, Piketty addresses the "devaluation of wealth" as a phenomenon that accompanied the cycles of accumulation of industry and the finance of capitalism in the nineteenth century and the first half of the twentieth century.

The devaluation of wealth is constitutive of the ever-revolutionary movement of capitalist expansion, described by Schumpeter (1942/1994) as "creative destruction". Marx dealt with crises as episodes of devaluation of existing capital, a phenomenon that arises from 
the bowels of accumulation, necessary to purge the weight of old wealth and to propel a new cycle of expansion (Mazzucchelli, 2004).

In the post-war period, economic policies were forged in the fear of re-editing the social and economic disaster of the Great Depression, aimed at stabilizing an economy with strong inclinations for instability.

The countercyclical policies of the Keynesian era fulfilled what they promised by halting the recurrence of "asset devaluation" crises. Nevertheless, by ensuring the value of existing wealth stocks, stabilization actions have broadened the role of wealth market valuation in corporate, consumer, and government decisions.

The interventions of last resort of central banks and National Treasuries, designed to avoid the deflation of assets, incited the conservation and valuation of wealth in its most sterile, abstract form, which, in contrast to the acquisition of machinery and equipment, does not carry any expectation of the generation of new value, of live employment. What was a way to avoid the destruction of abstract wealth is causing the necrosis of the economic fabric.

For Keynes (1936/2018), the "monetary economy of production", under the command of the money-commodity-money circuit (according to the insightful observation of Karl Marx) is constantly beset by the liquidity spectrum.

In the General Theory, Maynard drew attention to the importance of the contradictory relationships between the fetish of liquidity and investment decisions, the acquisition of new capital goods. The demand price of instrumental assets is calculated by discounting the expected yields from the market interest rate, the rate that expresses the willingness of wealth owners to give up liquidity. Chapter 17 of the General Theory is a digression on the decisions about the possession of wealth in the capitalist economy. The prospective valuation of real and financial assets is subdued to the radical uncertainty as to the possibility of converting values to the general form of wealth.

This is the inevitable result of investment markets organised with a view to so-called "liquidity". Of the maxims of orthodox finance none, surely, is more anti-social than the fetish of liquidity, the doctrine that it is a positive virtue on the part of investment institutions to concentrate their resources upon the holding of "liquid" securities. It forgets that there is no such thing as liquidity of investment for the community as a whole. The social object of skilled investment should be to defeat the dark forces of time and ignorance, which envelop our future. The actual, private object of the most skilled investment to-day is "to beat the gun", as the Americans so well express it, to outwit the crowd, and to pass 
the bad, or depreciating, half-crown to the other fellow. (Keynes, 1936/2018, chap. 12, p. 136).

Keynes continues:

This battle of wits to anticipate the basis of conventional valuation a few months hence, rather than the prospective yield of an investment over a long term of years, does not even require gulls amongst the public to feed the maws of the professional - it can be played by professionals amongst themselves. Nor is it necessary that anyone should keep his simple faith in the conventional basis of valuation having any genuine longterm validity. For it is, so to speak, a game of Snap, of Old Maid, of Musical Chairs - a pastime in which he is victor who says Snap neither too soon nor too late, who passed the Old Maid to his neighbour before the game is over, who secures a chair for himself when the music stops. These games can be played with zest and enjoyment, though all the players know that it is the Old Maid, which is circulating, or that when the music stops some of the players will find themselves unseated. (Keynes, 1936/2018, chap. 12, p. 136).

The the history of capitalism episodes of liquidity crises are frequent, always provoked after an expansion of credit created ex nihilo by the banking system. When euphoria becomes fear and uncertainty, rational agents become a rush of enraged buffaloes in search of "liquidity", that is, in capturing money in its generally essential determination of value and wealth.

The reserve function of money is very uncomfortable and intractable in equilibrium models. The Stochastic Dynamics of General Equilibrium models (Del Negro \& Schorfheide, 2013) do not contemplate money in its essential part of wealth. The elimination of this annoying character allows the "predominant" hypotheses to ignore the upward fluctuations and the "bass prices" collapses. These increasingly frequent episodes would be at the tail of the probability distribution. So-called "tail risk" - such as the valuation (and collapse) of asset backed securities - can not be considered as extended versions of small fluctuations. This is because the episodes of contagious euphoria and desperate search for liquidity deform the probability distribution itself.

It is opportune to recall that, in some models of general equilibrium, the rationality of agents is exercised in a space of relative "real" prices that guarantee ex-ante the balance of transactions in all dates and contingencies. In the hypotheses of the Austrian school of Von Mises to Hayek (1973), the "market process" is not based on the formalism of the general 
equilibrium, but results from the fluency and availability of information for all the protagonist individuals. The dynamics of the system is subject to the crucial and intertemporal decision that defines the preference of individual agents between present consumption and future consumption.

The division of income by the public between consumption and savings depends on the natural rate of interest. The natural rate reflects the "productivity of capital" in the sense of Wicksell, Böhm-Bawerk and other economists of the Austrian School. It is the rate that expresses the relation between present consumption and future consumption, that is, between the use of actual resources in the present (consumption) or in the future (savings/investment). Investment is a long and indirect process of access to consumption (roundaboutness), deferred consumption.

The theory of loanable funds (accumulated saving in bank deposits) is founded on the assumption that banks are to be mere intermediaries between savers and "spenders". Credit operations, mediated by the natural rate of interest, only redistribute positions between creditors and debtors, reflecting different preferences between present consumption and future consumption (investment) without any effect on macroeconomic stability. It is simply a redistribution of wealth. A's debt is B's credit: balance sheets change symmetrically and so there is no possibility of a "credit crisis" caused by excessive leverage.

Claudio Borio and Piti Disyatat (2011) explain that savings and financing are not equivalent (they are equivalent in the model, but not in general) and, more to the point, in the real world such interpretations of finance are largely based on text books on loanable funds this is a vision of finance excessively narrow and narrow because it ignores the role of monetary credit savings and financing are not equivalent in general. In a monetary economy, the constraint of (real) resources and the constraint of (monetary) cash flow differ because goods are not exchanged for goods, but for money or demand for it (credit). So credit and debt are not realized by the exchange of real resources, but by financial rights over those resources.

Piketty's studies of the role of public debt in the composition of private wealth in the early days of capitalism show the importance of asset-liability issued by governments in the transition from fixed assets on land to mobile and liquid wealth. Thus, the Bank of England mediated the trepidations and expropriations of primitive accumulation.

In the "financialized" capitalism of the twenty-first century, "rentier" income appropriation is closely associated with the swelling of national public debts. To understand the "new dynamics" of enrichment and inequality, it is necessary to evaluate, in Piketty's 
wake, the role of public indebtedness in valuing fictitious capital and the transmission of wealth between generations.

\section{Graphic 7. Average gross public debt as a percentage of GDP (\%)}

OECD, selected countries: 1970-2011

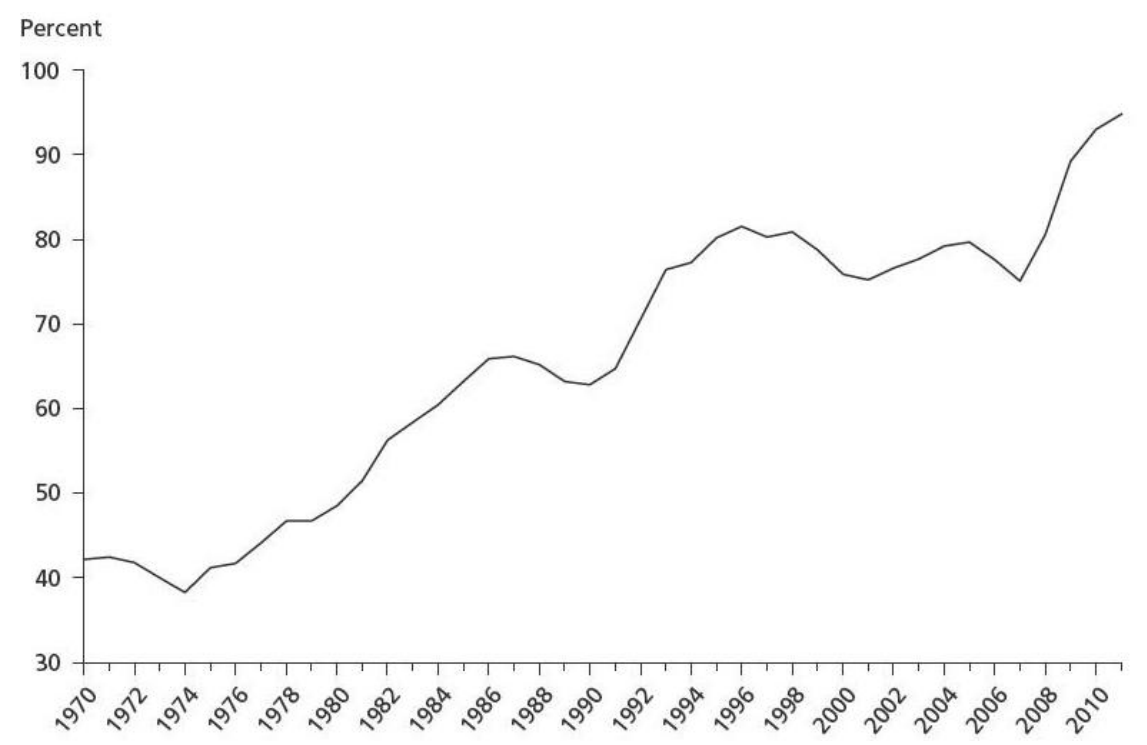

Countries: Austria, Belgium, Canada, France, Germany, Italy, Japan, Netherlands, Norway, Sweden, UK, USA. Source: OECD Ecomomic Outlook: Statistics and Projections (Database).

Government bonds are the "last resort" of global "securitized" financial markets. With regard to security and liquidity, there is a hierarchy between the sovereign bonds issued by the different countries, supposedly built from the "national" tax bases. However, this hierarchical scale reflects, above all, the hierarchy of national currencies, expressed in risk and liquidity premiums plus the basic interest rates of non-convertible currency countries.

The interest differential between those in the "periphery" and those prevailing in "developed" countries is determined by the "degree of confidence" that global markets are willing to give to the national policies of clients who manage coins with no international reputation.

\subsection{Quantitative easing and the metamorphoses of wealth}

In the 2008 crisis, the Federal Reserve and its peers in the developed world have not wavered. They sought to provide liquidity to manage deleveraging and contain at any cost the contraction of the interbank market and the evaporation of money markets. The central bank's balance sheets opened the floodgates to flood of assets with no price or reputation. 
The policy of liquidity flooding has discharged trillions into banks. The "independent" Federal Reserve used trillions of public dollars to buy private debts. The disproportionate expansion of the "money supply" did not generate inflation, much less engendered expansion of credit for production, frustrating supporters of quantitative theory.

The crisis has imposed on governments desperate moves to transform private liabilities into public debt. Central banks - some more, some less - took care of absorbing private assets in their balance sheets, while Treasuries were entrusted with the generous issuance of government bonds to support the liquidity of private banks' asset portfolios. It is not by chance that banks' profits are flat, turbinates urbi et orbi for treasury operations.

\section{Graphic 8. Aggregate balance sheet of large central banks (2000-2016)}

(US\$ trillions and as a percentage of GDP)

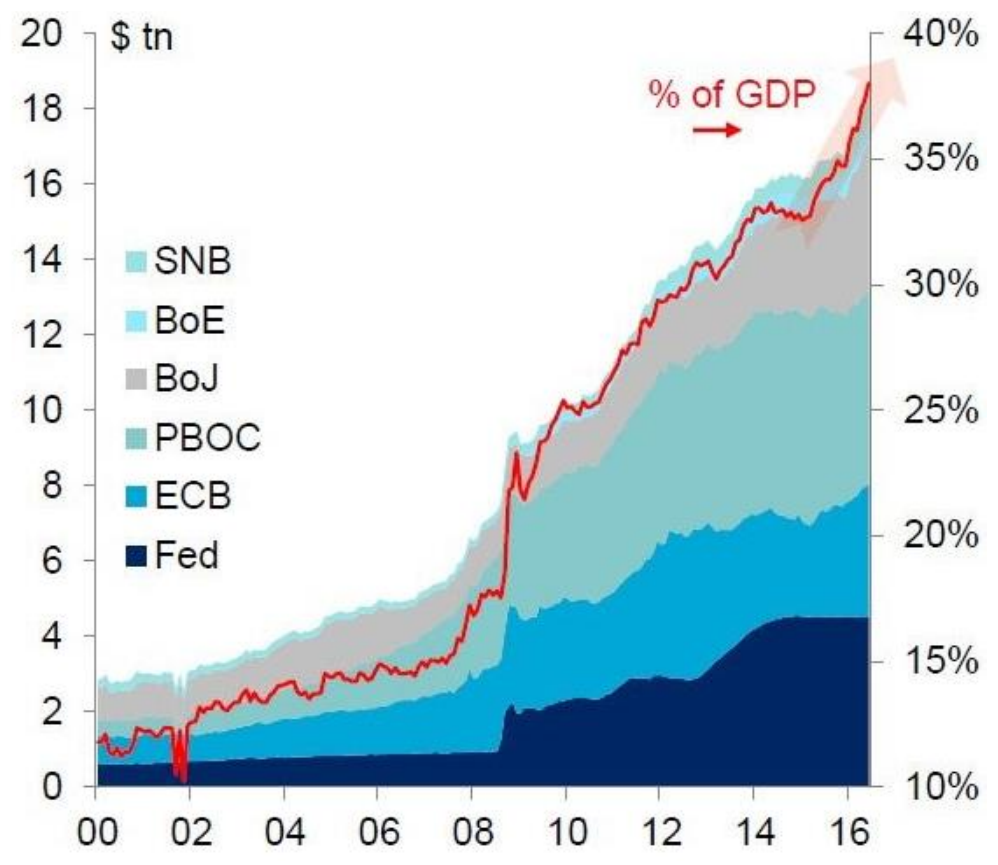

Source: Citi Research, Haver. Extracted from Smith (2017, May 31).

The experience of quantitative easing demonstrates the structural and contradictory articulation between the credit system, the productive accumulation of companies, private consumption and the management of the state's finances, particularly public debt. In the financial and banking crisis, the essentially "collectivistic" character of the monetary economy of production, that is to say capitalism, appears in the financial wreck as the lifeline to the wild private markets. The relations between public finances, monetary management and the private financial sector are not "external", mere interventionism. They 
are organic and constitutive. In times of "normality", the socialized forms of private power allow the wealth of each group to be diversified, to be distributed across several markets, and to ensure maximum equity gains, if possible in the short term. The agents of these operations are the institutions of private finance. They seek to anticipate price movements and to define hedging instruments and counterparty risks in contemporary financial markets. In the era of global finance, the integration of these markets has subjected the process of "pricing" of private and public assets denominated in currencies other than the anticipations about the yields of liquid and safe assets of last resort, issued by the issuing State of the reserve currency.

In conditions of uncertainty, banks and other financial institutions take care to anticipate the state of market liquidity according to expectations regarding the evolution of the balance sheets of companies, households, governments and countries, that is, changes in the relationships between prices of two stocks: the expected valuation of public and private assets and the assessments of the "quality" of the debts that finance their possession.

\section{Diagram 2. Global mechanism for transforming private debt into public debt (loss socialization)}

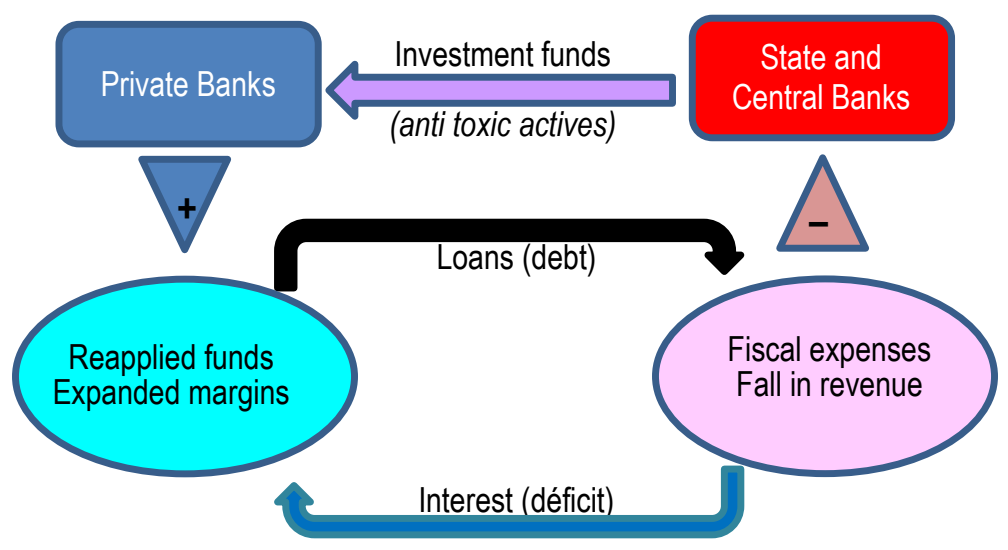

Note: Fiscal expenses $=$ revised and declassified tax chicks.

Analyzes and evaluations of the effects of quantitative easing almost always ignore the importance of expanding public debt for the sanitation and recovery of banks' balance sheets. Saved by the devaluation of the rotten assets they carried and now graze the central banks' balance sheet, private banks and other financial intermediaries have secured the quality of their portfolios and safeguarded their equity by carrying government bonds with reduced yields but assured valuation. Only the power of the State as the manager of the currency can guarantee the value of wealth. 
Graphic 9. Increase in government debt during the financial crisis (2007-2012)

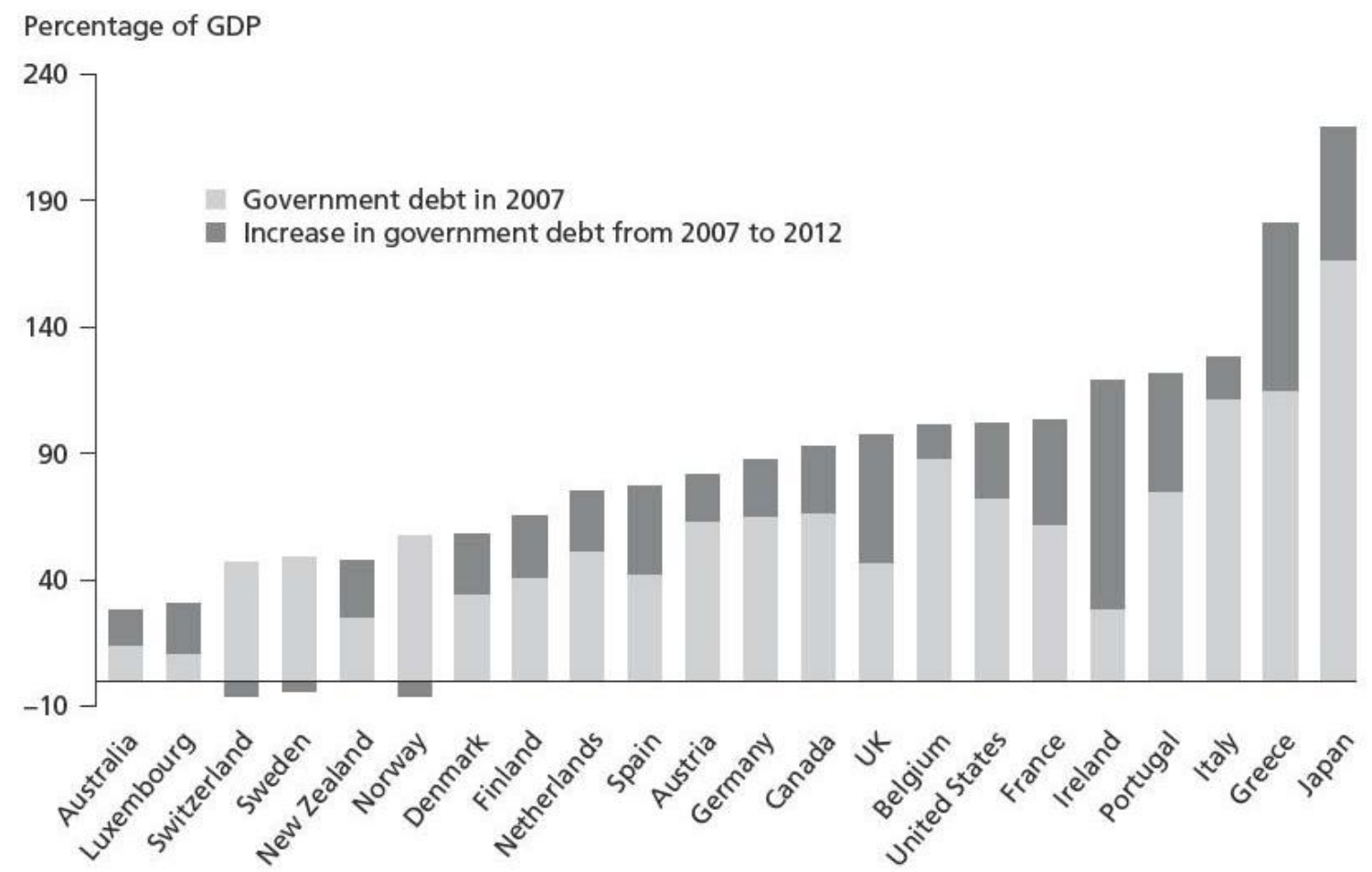

Source: OECD Economic Outlook, Statistics and Projections (Database).

Fixing the "price of money", the general form of wealth, by the central bank (basic interest rate) is intended to influence the movement of long rates and thus affect the changes in the composition margin of the portfolios (stocks of wealth financial and reproductive) of the owners of wealth, changes intermediated by the banking system. The long interest rate expresses, at each moment, the state of the expectations that inform the decisions of the holders of wealth, fearful among the uncertainties of creation of new wealth (the possession of a new reproductive asset) and the defense of the wealth already created through the shift of the portfolio to the most liquid assets. In moments of "liquidity crisis", portfolios are plunging massively into the asset that embodies the general form of wealth in the social imaginary and practice of private agents. However, if everyone runs into liquidity, few can. In the dance of the chairs, many are without seat. Only the provision of liquidity by the Central Bank saves. It stresses, but emphasizes the "liquidity preference" of banks, firms and households, driving divergences between the expansion of financial wealth and productive spending in income formation. 


\section{Graphic 10. Government and household indebtedness as a percentage of GDP}

USA: 1970-2012

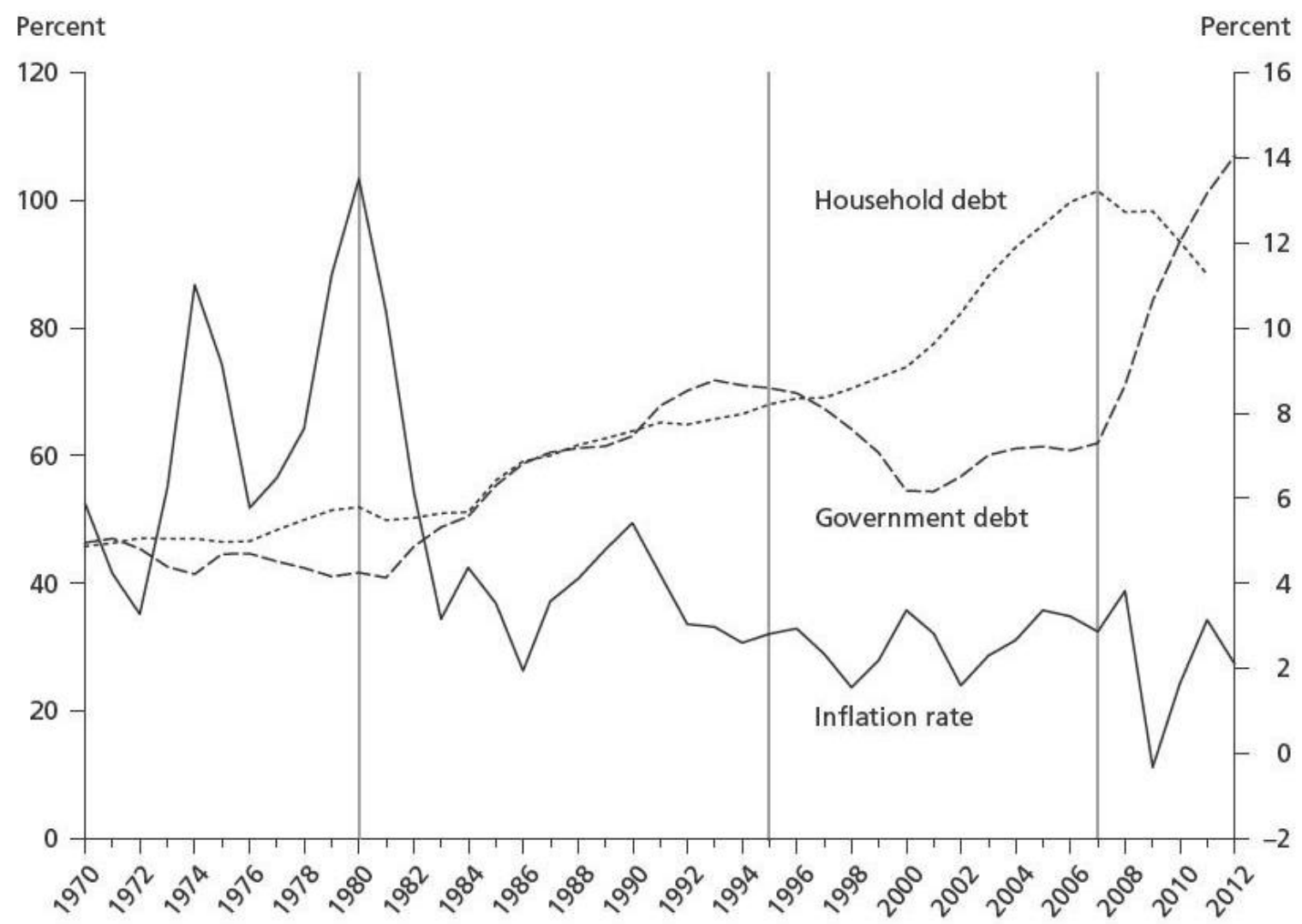

Source: OECD Economic Outlook: Statistics and Projections (Database).

A study by the Board of Governors of the Fed, released in November 2015, sheds light on this point. In response to the financial turmoil and the credit crunch associated with the global financial crisis, corporations have actively sought to raise liquid assets in order to accumulate financial assets and strengthen their balance sheets. If this kind of caution of companies has been relevant, this may have led to investments that are more fragile than normally expected and helps explain the weakness of the recovery of the global economy. In this sense, the counterpart of the decline in investment resources are increases in payments to investors in the form of dividends and repurchases of the shares themselves and, to a lesser extent, the high net accumulation of financial assets.

The expansion of liquidity finances the acquisition of existing real or financial assets (such as the repurchase of the shares themselves or the increase of liquid assets in order to accumulate financial assets and strengthen balance sheets), instead of financing the acquisition of goods and services, producing new asset bubbles. 
The $85^{\text {th }}$ BIS Annual Report for $2014 / 2015$ points to the inability of the dominant theory to assess what is happening in the "real world". The argument is compelling: if we purge the prevailing analytical view of its nuances and focus on its influence on the debate over economic policies, we are faced with a simple logic. There is an excess or deficiency of demand for domestic output (output gap), which determines inflation, or at least supports inflationary expectations. Advanced demand policies should be used, therefore, to eliminate the output gap and thus achieve full employment and the stability of the general level of prices, fiscal policies directly affect spending and monetary policy indirectly affects aggregate expenditure by managing the real interest rate. Fluctuating exchange rate allows the authorities the freedom to set monetary policy objectives. If each country adjusts its fiscal and monetary policies so as to close the product gap, period after period, everything is in the best of the worlds. Em adition, the report disqualifies economic policies that ignore financial globalization and its capital flows, insisting on measures that are always focused on the short term and aimed at "getting the house in order".

This Bank of International Settlements' report laments that, unfortunately, financial factors still float on the periphery of macroeconomic thinking. The intelligence gap has lingered in the aftermath of the crisis, despite the desperate efforts of 'serious economists' to push canonical models into banks and disruptive credit-debt relationships, sources of asset appreciation-devaluation cycles. The report will further stress the risks embedded in the behavior of post-crisis financial markets, pushed to another stock market bubble and high (and low yield) prices of private and public bonds. As the bubble grows, the performance of the "real economy" skims. The important point is the way credit is expanded. Instead of financing the acquisition of goods and services, which raises spending and output, credit expansion is simply financing the acquisition of existing assets, be they "financial" or "real" (estate or business) assets.

Low yields on US Treasuries encourage trading of assets on the Stock Exchanges and drive up asset prices. At all times, the companies dedicated themselves to the repurchase of the own actions and make the distribution of dividends with the easy money of the Federal Reserve.

The risks embedded in the behavior of post-crisis financial markets, pushed into another bubble in the Stock Exchanges, and high prices (and low yields) of private and public bonds are not negligible. Let it be said that in the "Western planet" it is the companies and banks that "fund" the stock markets by taking cheap credit to buy back the negotiated buybacks and to hold them in the treasury for the purpose of prices and please shareholders, providing earnings for stock option managers. 
Table 1. The 25 largest stock repurchasers among US-based corporations (2006-2015)

\begin{tabular}{|c|c|c|c|c|c|c|c|c|}
\hline Rank & Company Name & $\begin{array}{c}\text { Ticker } \\
\text { Symbol }\end{array}$ & $\begin{array}{c}\text { NI } \\
\text { USŞ bi }\end{array}$ & $\begin{array}{c}\text { BB } \\
\text { USŞ bi }\end{array}$ & $\begin{array}{c}\text { DV } \\
\text { USȘ bi }\end{array}$ & $\begin{array}{c}\mathrm{BB} / \mathrm{NI} \\
\%\end{array}$ & $\begin{array}{c}\mathrm{DV} / \mathrm{NI} \\
\%\end{array}$ & $\begin{array}{c}(\mathrm{DV}+\mathrm{BB}) / \mathrm{NI} \\
\%\end{array}$ \\
\hline 1 & Exxon Mobil & XOM & 349 & 206 & 93 & 59 & 27 & 86 \\
\hline 2 & Microsoft & MSFT & 174 & 124 & 58 & 71 & 33 & 105 \\
\hline 3 & IBM & IBM & 135 & 119 & 33 & 89 & 24 & 113 \\
\hline 4 & Apple & AAPL & 228 & 103 & 36 & 45 & 16 & 61 \\
\hline 5 & Procter \& Gamble & PG & 105 & 72 & 56 & 69 & 53 & 122 \\
\hline 6 & Cisco Systems & $\mathrm{CsCO}$ & 76 & 67 & 13 & 88 & 17 & 105 \\
\hline 7 & Hewllet-Packard & $\mathrm{HPQ}$ & 47 & 63 & 9 & 134 & 20 & 154 \\
\hline 8 & Pfizer & PFE & 90 & 63 & 68 & 70 & 76 & 146 \\
\hline 9 & Wal-mart & WMT & 152 & 61 & 48 & 40 & 31 & 71 \\
\hline 10 & Oracle & ORCL & 81 & 57 & 12 & 71 & 15 & 86 \\
\hline 11 & Intel & INTC & 90 & 54 & 37 & 60 & 41 & 101 \\
\hline 12 & General Eletric & GE & 149 & 52 & 88 & 35 & 59 & 94 \\
\hline 13 & Home Depot & $\mathrm{HD}$ & 45 & 50 & 19 & 111 & 42 & 153 \\
\hline 14 & Goldman Sachs & GS & 80 & 49 & 14 & 62 & 18 & 80 \\
\hline 15 & AT\&T & $\mathrm{T}$ & 115 & 47 & 93 & 41 & 81 & 122 \\
\hline 16 & Disney (Walt) & DIS & 55 & 46 & 11 & 83 & 20 & 103 \\
\hline 17 & Time Warner & TWX & 18 & 44 & 10 & 250 & 56 & 305 \\
\hline 18 & Johnson \& Johnson & $\mathrm{JNJ}$ & 126 & 42 & 61 & 34 & 49 & 82 \\
\hline 19 & Wells Fargo & WFC & 149 & 41 & 49 & 28 & 33 & 61 \\
\hline 20 & JPMorgan Chase & JPM & 166 & 41 & 51 & 25 & 31 & 55 \\
\hline 21 & Chevron & CVX & 188 & 40 & 62 & 21 & 33 & 54 \\
\hline 22 & AIG & AIG & -35 & 36 & 7 & -103 & -20 & -123 \\
\hline 23 & ConocoPhillips & COP & 60 & 36 & 31 & 61 & 52 & 113 \\
\hline 24 & PEPSICO & PEP & 60 & 36 & 30 & 59 & 50 & 109 \\
\hline 25 & McDonald's & $\mathrm{MCD}$ & 45 & 33 & 25 & 74 & 55 & 129 \\
\hline
\end{tabular}

Note: Net Income (NI); Stock Buybacks (BB); Cash Dividends (DV).

Source: Calculated from data downloaded from Standard \& Poor's Compustat database.

Extracted from Lazonick (2017, May 9).

Experience from the 2007 crisis shows that liquidity injections aimed at preventing price collapse and the paralysis of interbank markets have led to a collapse in asset prices but failed to revive the economy. The traditional Keynesian view supports its fiscal policy recommendations on the possibility of government action overcoming mistrust and private sector pessimism. The last decades have shown a strong tendency to rot in animal spirits of shareholders and corporate executives. Financial strategies value short-term gains and, therefore, stimulate share buyback programs (buying their own shares for the purpose of valuing them and favoring the distribution of dividends).

Thus, after the quantitative easing the liquidity assured by the Central Banks remains retained in the possession of the controllers of the fictitious capital, the real and financial trail of wealth already accumulated. Controllers of net wealth reject the possibility of seeing it in new wealth creation, for fear of losing it in the traps of surplus capacity and disguised unemployment in precarious jobs with falling yields. 
Helpless from the buoyancy of demand, Central Banks lower their interest rates to sub-zero, they attempt to mobilize the liquidity of credit for the demand for real assets over time. Still intoxicated by the metabolism of the ingested assets in their balance sheets to save the financial system in 2008 , governments hesitate to stimulate the economy by fiscal policy.

\section{Financial dominance, rising inequality, and effective demand}

Until the mid-1970s, as discussed above, developed economies thrived in an environment of productivity gains, investment-oriented credit systems, real wage increases, reduction of inequalities, and expansion of social rights.

In its "Fordist" format, this circuit was primarily driven by the demand for credit to finance business spending, relying on the reciprocal effects of the expansion of workers' income, corporate profits and small and medium-sized enterprises in commerce and industry. The income and employment circuit then developed in national spaces, fostering a deepening of relations between manufacturing, services and agriculture.

In the early twentieth century, the capitalist Henry Ford had already understood that wages, in addition to cost to companies, are also a source of demand for their automobiles. He understood that the formation of aggregate income and demand depends on the willingness of the entrepreneurs to spend on wages and other means of production that also employ wage earners. When deciding to spend on the payment of wages and to put its productive capacity in operation or to decide to increase it, the business collective evaluates the perspective of return of its expenditure imagining the expenditure of the others.

Marx's understanding of this subject, expressed in the Grundrisse (written between 1957-1861), remains valid. He argues that the relation of each capitalist to his workers is in fact the relation of capital and labor, the essential relation. However, it is precisely from this that the illusion - true to the individual capitalist - that, apart from its workers, the rest of the working class is confronted with it, not as workers but as consumers and exchangers (money-spenders). Therefore, capital itself considers the demand of the workers - and the payment of the wage on which this demand is based - not as gain but as loss. In this sense, capital presents itself as a peculiar form of the relation of domination precisely because the worker confronts him as a consumer and holder of exchange value, in the form of a possessor of money. Therefore, by its nature, capital posits a barrier to labor and value-creation in contradiction to its tendency to expand them boundlessly. And in as much as it both posits a barrier specific to itself, and on the other side equally drives over and beyond every barrier, it is the "living contradiction" (Marx, 1861/1993). 
After the crisis of 2008, the central economies are squeezed in the distress of families' deleveraging and, therefore, they are dealing with the rupture of a crucial link of the training circuit of employment and income.

In their contradictory progress, the spatial redistribution of manufacturing, hyper industrialisation, and engorgement of rentier financial wealth led to the precariousness of employment, the fall in workers' incomes, and thus reduced the ability to diffuse corporate spending and discouraged demand. As has been said above, in the last cycle of global euphoria, households subjected to slow income developments sustained the expansion of consumption in the dizzying expansion of credit, which creates additional purchasing power for low-income and middle-income households, at the same time as imprisons them in the infernal cycle of increasing indebtedness. At the top of the wealth and income distribution pyramid, liquid creditors fatten their portfolios by valuing real estate and financial assets.

Holders of financial wealth are also entitled to the "free time" created by the technological advance that simultaneously promotes the disqualification of the salaried mass and the polarization of the labor market. In turn, the "disqualified" workers become chronic dependents of indebtedness, always threatened by unemployment and, therefore, forced to compete desperately for survival.

The restructuring of capitalism involved profound changes in the way companies operate, market integration and State sovereignty. The true meaning of globalization is the intensification of competition among companies, workers and nations, embedded in a monetarily hierarchical global financial structure, commanded by the power of the dollar.

Under the auspices of financial capital and an asymmetric international monetary system, the brutal centralization of control over production decisions, location and profit utilization in a small core of large corporations and financial institutions worldwide. The centralization of control boosted and was driven by the spatial fragmentation of production.

The convergence between the centralization of control by finance and the spatial fragmentation of production was fostered and accompanied by the deepening of the interrelationships between commercial banks, investment banks, insurance companies, pension funds and hedge funds. The centralization of command in financial capital profoundly altered the strategy of the great productive enterprise.

In the United States, the volume of credit to finance positions in existing assets has grown at a much faster pace than that of loans for productive expenditure. As a proportion of GDP, the value of bank loans to other financial institutions is now four times higher than credits intended to finance job creation and income in the productive sector. 
The ratio between investment funds and those used to promote a "joint" increase in shareholder earnings and stock options was altered. In the 1960s, times of the Berle and Means oligopolies and managers obsessed with the company's growth in the long run, every US\$ 12 spent on buying machines or building new factories, only US\$ 1 was spent on the dividends paid shareholders. In the following decades, the proportion began to reverse: more dividends, more "interest on own capital" and less investment in factories and the hiring of workers.

The association of interests between managers and shareholders stimulated the purchase of shares of the companies themselves with the purpose of valuing them and favoring the distribution of dividends. This is compounded by the fever of mergers and acquisitions, tax planning in tax havens, the drowning of quarterly profit and loss accounts, and the afflictions of companies and banks flogging with mark to market.

In the article "The financialization of the US corporation", economist William Lazonik (2013, p. 858) wrote:

Since the beginning of the 1980 s, employment relations in U.S. industrial corporations have undergone three major structural changes - which I summarize as "rationalization", "marketization", and "globalization" that have permanently eliminated middle-class jobs. From the early 1980s, rationalization, characterized by plant closings, eliminated the jobs of unionized blue-collar workers. From the early 1990s, marketization, characterized by the end of a career with one company as an employment norm, placed the job security of middle-aged and older white-collar workers in jeopardy. From the early 2000s, globalization, characterized by the movement of employment offshore, left all members of the U.S. labor force, even those with advanced educational credentials and substantial work experience, vulnerable to displacement.

These structural changes in employment were driven by the pursuit of strategies aimed simply at financial gains. Many companies closed down factories, eliminated more expensive and more experienced workers, shifted production to other countries at the expense of long-term competitiveness.

\section{Final remarks}

In its current configuration, capitalism has shown the inability to deliver what it promises to citizens. Exclusion manifests itself in youth unemployment, structural 
unemployment promoted by technological change and migration from manufacturing to lowwage regions.

The debates over Brexit, as well as the speeches of Trump and Sanders in the United States, smear the ingenuity of the binary debate between progressives and conservatives. In this two-stroke time, the false dichotomy "more market and less State" or "less market and more State" hides the private appropriation of the State and the public space to imprison free individuals in the entanglements of mercantile despotism and the monopoly of opinion.

The poet and literary critic Anis Shivani invaded the terrain of social criticism to write an admirable text about the perils of neoliberalism. He beats up the decoys that mislead defenders and opponents of the regime of probation. It is a mistake, he says, to imagine that neoliberalism is the return to classical liberalism. Neoliberalism presupposes a strong state, operating exclusively for the benefit of the rich and powerful, without any pretense of neutrality and universality. Capitalism as a form of control of society and of human life found its epiphany in technological change, in the control of global markets by big business. Shivani (2016, June 6) suggests that, instead of claiming social protection as a legitimate right, citizens feel guilty, vexed and depressed because of their reliance on government programs.

Convinced of their freedom, free individuals give their destiny to the fetters of competition and the illusions of meritocracy. Disturbed by their guilts, the losers are accommodated to the torments of exclusion and inequality. Hegel would say that capitalism fulfilled its concept.

Citizens are haunted by the economic ghosts, and "you cannot be dictated to by thousands of faceless civil servants who make these rules", as actor Michael Caine said in his defense of Britain's exit from the European Union (BBC News, 2016, January 22). Rulers hauled by the favors and powers of high finance seek to cut off the social and economic rights of their citizens while proclaiming the efficiency of markets. Under the pretext of confronting corporatism and the resistance of "acquired rights", the servants of globalization propose a return to primitive patterns in the relations between the forces of capital and the weaknesses of labor. They advocate the shrinkage of the system of social protection created to prevent the misery of the weak, the suffering of the common man tormented by the threats of precariousness and helplessness in health and illness.

These are the principles that have driven the "reforms", both those of the developed countries and the ones mimicked by the rulers of peripheral countries. They judge, with these programs, to be buying the ticket for the club of the rich. They are actually exchanging health, the education of the people and the quiet of the old by mirages. 
Several political analysts have found that there is a crisis of democratic regimes in the European Union. The Democracy in Europe Movement 2025 (DiEM25), a pan-European political movement launched in 2015 by former Greek Finance Minister Yanis Varoufakis and Croatian philosopher Srećko Horvat, is based on a diagnosis that there isn't a full-fledged democracy. From his point of view, real democracy assumes that citizens not only elect but also take part in decisions directly by building social agreements. In fact, we are living in an age in which democracy is just a promise in most countries, because it is a financial and media oligarchy that rules the world. In adition, Brexit and the American elections express nonconformity with the narrowing of democratic space and the desire of citizens to decide on their own lives in the exercise of politics.

As was said above, the "social" and "inter-national" capitalism of the "golden age" was transfigured into "global", "financially" and "unequal" capitalism. ${ }^{1}$ "Domestic" economic policies are limited by the pursuit of conditions imposed by the engorgement of wealthproperty and by the loose labor market, despite official misleading figures of unemployment.

Economic disarticulation reveals a new phase, marked by disagreements in the relations between the functioning of globalized markets and national or only partially "internationalized" legal-political spaces, such as the European Union and, worse, the Eurozone. The feasibility of unilateral solutions is doubtful. Yanis Varoufakis (2017, January 23) justified his stance against EU exit arguing that it is unlikely that going out will take you where you would be economically and politically if you had not.

A recent survey of the Pew Research Center (across 10 European nations) estimated a median of $62 \%$ favorable toward the European Union, but only $50 \%$ in favor to the European Parliament. The most worrying fact is that Europeans also tend to describe Brussels as inefficient and intrusive, and in particular they believe the EU is out of touch - a median of $62 \%$ say it does not understand the needs of its citizens (Wike, Fetterolf \& Fagan, 2019, March 19).

Open and disguised unemployment, precariousness and concentration of income have advanced in the wealthy world. The growth of part-time and precarious workers was escorted by the destruction of jobs in the manufacturing industry. The evolution of the "precariat", the new dangerous class (Standing, 2011), constituted subordination relations of the workers that develop under the practices of flexibility of the schedule, tempered with the delights of work "at home". This "flexibility" makes the worker permanently available to respond to the demands of the employer or contractor.

\footnotetext{
${ }^{1}$ It is important to stress that Trotsky's notion of "uneven and combined development" remains valid
} for understanding contemporary capitalism (Ashman, 2009). 
A study on the rising income polarization in the United States, published by the IMF, shows how the reflexes of these movements are felt more dramatically in the middle class (Alichi, Kantenga \& Solé, 2016). Middle-income people who accounted for approximately $58 \%$ of the US population in the 1970 s had their share cut to $47 \%$ by 2014 . The polarization trend is consistent for different middle-income definition cuts. The exclusion of the richest $1 \%$ or analyzes considering age, race or education produce the same result.

The participation data of the different levels of income in the economy corroborate the polarization observed in the population. The average income share in the US economy was $47 \%$ in 1970 and fell to approximately $35 \%$ in 2014 . The counterpart of this decrease can be observed in the increase of the participation of the high income, since there is no gain for the low income during the whole period. The study concludes that this movement is explained by the low dynamism of the labor market in the United States. Note that the typical salary of an American worker grew by only $11 \%$ in the same period.

The underemployed and the precarious are furious at what economists think about Brexit's risks or Trump's uncertainties. The victory of the xenophobic nationalism of Donald Trump in the US, the exit of the United Kingdom from the European Union, the tension between Germany and Mr. Mario Draghi's monetary policy in the Euro Zone, Japan on the brink of recession, and the Chinese downturn are events that point to far-reaching changes in the dynamics of the world economy resulting from the fracture of the geo-economic arrangement erected in the last 40 years.

Political polarization dramatically expresses the rupture of the more "balanced" relations between the powers of the "free market" and the protection of the economic and social rights of disadvantaged citizens, deepened by the lethargy of the global economy.

\section{References}

Alichi, A., Kantenga, K., \& Solé, J. (2016). Income polarization in the United States. [IMF Working Paper, wp/16/121], International Monetary Fund, Washington. Retrieved from: https://www.imf.org/external/pubs/ft/wp/2016/wp16121.pdf

Ashman, S. (2009). Capitalism, uneven and combined development and the transhistoric, Cambridge Review of International Affairs, 22(1), 29-46. doi:10.1080/09557570802683896

Bank of International Settlements (2015, June 28). BIS Annual Economic Report 2014/2015 (85th ed.). Basel, Switzerland. Retrieved from: https://www.bis.org/publ/arpdf/ar2015e.pdf

BBC News (2016, January 22). Sir Michael Caine "sort of certain" UK should quit EU. [Site]. Retrieved from: https://www.bbc.com/news/uk-politics-eu-referendum-35380299 
Belluzzo, L. G. M. (2016). The recent internationalization of capitalization. In A. Bárcena \& A. Prado (Eds.). Neostructuralism and heterodox thinking in Latin America and the Caribbean in the early twenty-first century (pp. 101-114). Santiago, Chile: Economic Commission for Latin America and the Caribbean (ECLAC).

Belluzzo, L. G. M., \& Galípolo, G. (2017). Manda quem pode, obedece quem tem prejuízo. São Paulo: Editora Contracorrente.

Belluzzo, L. G. M., \& Galípolo, G. (2019). A escassez na abundância capitalista. São Paulo: Editora Contracorrente.

Bertocco, G. (2017). Crisis and the failure of economic theory: The responsibility of economists for the Great Recession. Cheltenham, UK: Edward Elgar.

Borio, C. (2013). On time, stocks and flows: Understanding the global macroeconomic challenges. National Institute Economic Review, 225(1), 3-13.

Borio, C., \& Disyatat, P. (2011). Global imbalances and the financial crisis: Link or no link? [BIS Working Papers n. 346], Bank for International Settlements, Basel, Switzerland.

Chandrasekhar, C. P., \& Ghosh, J. (2018). A decade of speculation. Economic and Labour Relations Review, 29(4), 410-427.

Del Negro, M., \& Schorfheide, F. (2013). DSGE model-based forecasting. In G. Elliott \& A. Timmermann (Eds.) Handbook of economic forecasting (Vol. 2, part A, chap. 2, pp. 57-140). Amsterdam: North Holland.

Godley, W., \& Lavoie, M. (2007). Monetary economics: An integrated approach to credit, money, income, production and wealth. New York: Palgrave Macmillan.

Hayek, F. A. (1973). Law, legislation and liberty (Vol. 1: Rules and order). Chicago: University of Chicago Press.

Keynes, J. M. (1936/2018). The general theory of employment, interest and money. Cambridge: Palgrave Macmillan. (eBook: https://doi.org/10.1007/978-3-319-70344-2)

Keynes, J. M. (1973). The General Theory and after, Part II. In D. Moggridge (Org.). The collected writings of John Maynard Keynes (Vol. XIV). London: Macmillan.

Lazonik, W. (2013). The financialization of the US corporation: What has been lost, and how it can be regained. Seattle University Law Review, 36(2), 857-909.

Lazonik, W. (2017, May 9). How the U.S. new economy business model has devalued science \& engineering PhDs. Institute for New Economic Thinking. Retrieved from: https://www.ineteconomics.org/perspectives/blog/marketization-and-financialization

Marx, K. (1894/1984). O capital. Crítica da economia política (Livro 3, tomo 1). São Paulo: Abril Cultural.

Marx, K. (1861/1993). Grundrisse: Foundations of the critique of political economy (Draft). London: Penguin Books. 
Mazzucchelli, F. (2004). A contradição em processo: O capitalismo e suas crises (2nd ed.). Campinas, SP: Unicamp.IE.

Minsky, H. (1983). Money and crisis in Schumpeter and Keynes. [Hyman P. Minsky Archive, Paper 334], Bard Digital. Retrieved from: http://digitalcommons.bard.edu/hm_archive/334

Minsky, H. (1986). Stabilizing an unstable economy. New Haven: Yale University Press.

Piketty, T. (2014). Capital in the twenty-first century. Cambridge: Harvard University Press.

Piketty, T., \& Zucman, G. (2014). Capital is back: Wealth-income ratios in rich countries 17002010. The Quarterly Journal of Economics, 129(3), 1255-1310.

Rutkowski, R. (2014, May 1). Are higher costs impacting Chinese export competitiveness? China Economic Watch, Peterson Institute for International Economics (PIIE). Retrieved from: https://www.piie.com/blogs/china-economic-watch/are-higher-costs-impacting-chinese-exportcompetitiveness

Schumpeter, J. A. (1942/1994). Capitalism, socialism and democracy. London: Routledge.

Shivani, A. (2016, June 6). This is our neoliberal nightmare: Hillary Clinton, Donald Trump, and why the market and the wealthy win every time. Salon. Retrieved from: https://www.salon.com/2016/06/06/this_is_our_neoliberal_nightmare_hillary_clinton_donald_trump_a nd_why_the_market_and_the_wealthy_win_every_time/

Smith, C. H. (2017, May 31). The Keynesian cult has failed: "emergency" stimulus is now permanent. SNB and CHF. Retrieved from: https://snbchf.com/2017/05/hugh-smith-keynesian-cultemergency-stimulus/

Standing, G. (2011). The precariat: The new dangerous class. London: Bloomsbury Academic.

Tselichtchev, I. (2012). China versus the West: The global power shift of the 21st century. Singapore: John Wiley \& Sons Singapore.

United Nations Conference on Trade and Development (2003). Unctad Trade and Development Report 2003: Capital accumulation, growth and structural change. New York and Geneva: United Nations.

Varoufakis, Y. (2017, January 23). A New Deal to save Europe. Project Syndicate. Retrieved from: https://www.project-syndicate.org/commentary/new-deal-for-europe-by-yanis-varoufakis-201701 ?barrier=accesspaylog

Wike, R., Fetterolf, J., \& Fagan, M. (2019, March 19). Europeans credit EU with promoting peace and prosperity, but say Brussels is out of touch with its citizens. Pew Research Center [Site]. Retrieved from: https://www.pewresearch.org/global/2019/03/19/europeans-credit-eu-withpromoting-peace-and-prosperity-but-say-brussels-is-out-of-touch-with-its-citizens/

Received on 02 September 2019

Approved on 07 October 2019 